HAUNTING HISTORY 
This page intentionally left blank 
Crossing Aesthetics

Werner Hamacher

Editor 
Stanford

University

Press

Stanford

California

2017 


\section{HAUNTING HISTORY}

For a Deconstructive Approach to the Past

Ethan Kleinberg 
Stanford University Press Stanford, California

(C) 2017 by the Board of Trustees of the Leland Stanford Junior University. All rights reserved.

No part of this book may be reproduced or transmitted in any form or by any means, electronic or mechanical, including photocopying and recording, or in any information storage or retrieval system without the prior written permission of Stanford University Press.

Printed in the United States of America on acid-free, archival-quality paper

Library of Congress Cataloging-in-Publication Data

Names: Kleinberg, Ethan, 1967- author. Title: Haunting history : for a deconstructive approach to the past / Ethan Kleinberg.

Other titles: Meridian (Stanford, Calif.)

Description: Stanford, California :

Stanford University Press, 2017. I

Series: Meridian: crossing aesthetics I Includes bibliographical references and index.

Identifiers: LCCN 20160574321

ISBN 9781503602373 (cloth : alk. paper) I

ISBN 9781503603387 (pbk. : alk. paper) I

ISBN 9781503603424 (e-book)

Subjects: LCSH: History-Philosophy. I History-Methodology. I Historiography. I Deconstruction. Classification: LCC Di6.8 .K495 2017 I DDC 90I-dc23 LC record available at https://lccn.loc.gov/2016057432 